\title{
Validasi bahan ajar menulis teks nonfiksi berbasis pendekatan genre
}

\author{
Wulan Arum Sari a, ${ }^{*}$, Burhan Nurgiyantoro ${ }^{\text {b, } 2}$ \\ a Mahasiswa Pendidikan Bahasa dan Sastra Inonesia, Fakutas Pascasarjana , Universitas Negeri Yogyakarta \\ b Dosen Pendidikan Bahasa dan Sastra Indonesia, Fakultas Bahasa dan Sastra, Universitas Negeri Yogyakarta \\ Iwulanarum77@gmail.com ; ${ }^{2}$ burhan@uny.ac.id \\ *korespondensi penulis

\begin{tabular}{ll}
\hline Informasi artikel & \\
\hline Sejarah artikel: & \\
Diterima & $: 6$ Februari 2020 \\
Revisi & $:$ I8 April 2020 \\
Dipublikasikan & $: 30$ April 2020 \\
\hline
\end{tabular} \\ ABSTRAK \\ Penelitian ini bertujuan untuk mendeskripsikan kevalidan bahan ajar menulis teks \\ nonfiksi berbasis pendekatan genre. Pendekatan genre adalah pendekatan yang \\ menekankan pada jenis teks. Jenis penelitian yaitu deskriptif kualitatif. Data yang \\ diperoleh berasal dari penilaian ahli (dosen), guru, dan siswa. Subjek dalam \\ Kata kunci: \\ penelitian ini adalah tiga ahli dan lima guru bahasa Indonesia, serta 44 siswa kelas \\ Validasi \\ Menulis \\ Nonfiksi \\ VIII sebagai responden. Teknik pengumpulan data dilakukan dengan angket. \\ Genre \\ Instrumen pengumpulan data berupa lembar validasi ahli, lembar penilaian guru, \\ dan lembar respon siswa. Hasil penelitian ini menunjukkan bahan ajar menulis teks \\ nonfikdi berbasis pendekatan genre berdasarkan velidasi ahli, penilaian guru, dan \\ respon siswa memperoleh persentase skor $82,36 \%$ berkategori baik sehingga dapat \\ disimpulkan bahwa semakin tinggi skor yang diperoleh, semakin baik pula hasil \\ kevalidan produk tersebut.

\section{Key word: Validation \\ Writing \\ Nonfiction \\ Genre}

\begin{abstract}
This research aims to describe the validity of teaching materials in writing nonfiction texts based on genre approach. The genre approach is an approach that emphasizes text types. The type of research is descriptive qualitative. The data obtained comes from the assessment of experts (lecturers), teachers, and students. The subjects in this study were three experts and five Indonesian language teachers, and 44 eighth grade students as respondents. The technique of collecting data is done by using a questionnaire. Data collection instruments include expert validation sheets, teacher assessment sheets, and student response sheets. The results of this study indicate nonfikdi text writing materials based on a genre approach based on expert velidation, teacher ratings, and student responses get a percentage score of $82.36 \%$ with good category so it can be concluded that the higher the score obtained, the better the validity results of the product.
\end{abstract}

\section{Pendahuluan}

Keterampilan berbahasa Indonesia terdiri atas keterampilan menyimak, keterampilan membaca, keterampilan berbicara, dan keterampilan menulis. Keempat keterampilan tersebut saling berhubungan sata sama lain. Setiap keterampilan mempunyai peran masing-masing.

Keterampilan menulis merupakan keterampilan nomor empat dan dianggap sebagai keterampilan yang kompleks. Dikatakan kompleks karena sebelum seseorang mampu menulis, ia harus mampu menguasai keterampilan sebelumnya yaitu keterampilan menyimak, keterampilan, membaca, dan keterampilan berbicara. Keempat komponen ini dibutuhkan oleh setiap orang untuk mencapai kesuksesan dalam tulisan mereka (Donoghue, 2009: 254)

Nurgiyantoro (2016: 464) mengemukakan bahwa menulis merupakan kegiatan mengungkapkan gagasan melalui bahasa. Tulisan yang baik adalah
Copyright (C) 2018 Universitas Ahmad Dahlan. All Right Reserved tulisan yang mengungkapkan gagasan secara efektif dan efisien sehingga tulisan tersebut mampu dipahami oleh pembaca (Johnson, 2008: 2II).

Pembelajaran di sekolah tidak lepas dari kegiatan menulis. Oleh karena itu, menulis merupakan alat yang diperlukan dalam kegiatan belajar (Graham, dkk, 20I2: 3). Kegiatan menulis bertujuan supaya siswa mempunyai rasa cinta terhadap tulisan karena lewat tulisan siswa dapat berbagi pengalaman dani lmu pengetahuan.

Kenyataanya, masih ada siswa yang mengalami kesulitan dalam menulis. Mereka tidak tahu tujuan mereka menulis dan apa yang akan mereka tulis, khususnya teks nonfiksi. Nonfksi merupakan teks yang berisi informasi mengenai suatu kejadian yang nyata atau real (Kersten, 2007: 36; Harper, 2013: 25).

Penguasaan materi di sekolah berkaitan dengan penggunaan bahan ajar. Bahan ajar merupakan segala bentuk bahan ajar yang digunakan untuk kegiatan belajar di kelas (Daryanto \& Dwicahyono, 20I4: 
I7I). Bahan ajar dapat berupa bahan ajar cetak maupun bahan ajar noncetak. Penggunaan bahan ajar dapat membantu guru dalam mengarahkan kegiatan pembelajaran yang lebih efektif dan efisien karena guru mempunyai panduan materi yang jelas (Thamrin, 2014: 90).

Berdasarkan observasi yang dilakukan didua sekolah, SMPN 2 Dlingo dan SMPN 4 Pandak. Sekolah tersebut menggunakan bahan ajar dari Kemendikbud edisi revisi 2017 dan Lembar kerja Siswa (LKS). Buku ajar yang digunakan mencakup semua keterampilan yaitu menyimak, membaca, berbicara, dan menulis sehingga penjelasan tiap keterampilan kurang mendalam.

Materi yang disajikan dalam buku tersebut berupa pengertian, materi, dan tugas. Contoh masih kurang. Hal tersebut dianggap kurang lengkap tanpa adanya materi mengenai langkah-langkah dan contoh dalam menulis teks nonfiksi. Siswa tentu akan mudah memahami materi apabila di dalam buku disediakan contoh langkah-langkah menulis.

Pranowo (2017: 238) mengemukakan bahwa guru memiliki tugas untuk menjabarkan materi agar menjadi bahan ajar yang lengkap. Materi pembelajaran perlu ditentukan dengan tepat karena setiap materi memerlukan teknik, strategi, maupun pendekatan yang berbeda-beda. Oleh karena itu, pemilihan teknik, strategi, maupun pendekatan penting untuk dilakukan agar materi yang disampaikan dapat dipahami siswa dengan baik.

Pendekatan yang dinilai cocok untuk mengembangkan bahan ajar tersebut adalah pendekatan genre. Genre dapat didefinisikan sebagai jenis teks yang berfungsi sebagai pola rujukan sehingga suatu teks dapat dibuat dengan efektif, efektif dari sisi ketepatan tujuan, pemilihan dan penyusunan teks, serta ketepatan dalam penggunaan tata bahasa (Pardiyono, 2007: 2). Langkah pengembangan bahan ajar menulis teks nonfiksi berbasis pendekatan genre yaitu pemodelan, mengonstruksi teks secara berkelompok, dan mengonstruksi teks secara mandiri (Cope \& Klantzis, 1993: II; Hyland, 2003: 2I; Knapp \& Watkins, 2005: 78). Hal tersebut akan memudahkan siswa untuk belajar menulis teks nonfiksi.

Tujuan penelitian ini adalah untuk mengetahui tingkat kevalidan bahan ajar menulis teks nonfiksi berbasis pendekatan genre. Selain itu, dengan adanya penelitian ini dapat diketahui sejauh mana bahan ajar ini dapat diterima baik dari guru maupun siswa.

\section{Metode}

Penilitian ini merupakan jenis penelitian deskriptif kualitatif. hasil yang berupa data kemudian dideskripsikan. Data yang diperoleh berasal dari penilaian ahli (dosen), guru, dan siswa. Subjek dalam penelitian ini adalah 3 ahli dan 5 guru bahasa Indonesia, serta 44 siswa kelas VIII sebagai responden. Teknik pengumpulan data dilakukan dengan angket. Instrumen pengumpulan data berupa lembar validasi ahli, lembar penilaian guru, dan lembar respon siswa. Aspek yang dinilai yaitu aspek kelayakan isi, aspek kelayakan penyajian, aspek kelayakan bahasa, dan aspek kelayakan kegrafikan.

Validasi ahli, penilaian guru, dan respon siswa dilakukan dengan pengklasifikasian Skala Likert dengan lima pilihan jawaban. Skala tersebut dimulai dari "I" sampai "5" dengan rentangan sangat baik, baik, cukup baik, kurang baik, dan sangat kurang baik.

Langkah-langkah analisis hasil validasi yang dilakukan oleh ahli, penilaian dari guru bahasa Indonesia, dan respon siswa sebagai berikut.

1. Data yang diperoleh dari ahli kemudian diubah menjadi data kualitatif.

2. Menghitung persentase dengan skor yang diperoleh kemudian dibagi skor maksimal dikalikan $100 \%$.

3. Hasil persentase kemudian interpretasikan. Kriteria interpretasi skor sebagai berikut (Riduwan, 2015: I5).

Tabel I. Kriteria Interpretasi Skor

\begin{tabular}{cc}
\hline Kriteria & Persentase Skor \\
\hline Sangat Baik & $8 \mathrm{I}-\mathrm{I00} \%$ \\
\hline Baik & $6 \mathrm{I}-80 \%$ \\
\hline Cukup & $4 \mathrm{I}-60 \%$ \\
\hline Kurang & $2 \mathrm{I}-40 \%$ \\
\hline Sangat Kurang Baik & $0-20 \%$ \\
\hline
\end{tabular}

Tabel I tersebut digunakan untuk menentukan validasi produk yang dikembangkan. Produk dinyatakan valid apabila persentase skor yang didapat minimal antara 4I-60\% menempati kategori "Cukup Baik”.

\section{Hasil dan pembahasan}

Data yang diperoleh dari penelitian ini yaitu data yang diperoleh dari validasi produk oleh ahli, data yang diperoleh dari penilaian guru, dan data yang diperoleh dari respon siswa. Data tersebut, kemudian dikonversi dengan menggunakan kriteria interpretasi skor untuk mengetahui valid atau tidaknya produk yang dikembangkan. Produk yang dinyatakan layak apabila skor yang didapat minimal antara 4I-60\% menempati kategori "Cukup Baik" (Riduwan, 2015: I5). 
Validasi produk pengembangan bahan ajar menulis teks nonfiksi dilakukan oleh ahli dan guru. Sedangkan siswa memberikan respon terhadap produk. Penilaian yang diberikan meliputi empat aspek, yaitu aspek kelayakan isi, aspek kelayakan penyajian, aspek kelayakan bahasa, dan aspek kelayakan kegrafikan. Data hasil validasi diperoleh dengan memberikan centang $(\sqrt{ })$ pada rentang skor I5. Selain itu, ahli juga memberikan kritik dan saran pada lembar validasi. Rekapirulasi data hasil validasi ahli disajikan pada tabel 2 .

Tabel 2. Rekapitulasi Hasil Validasi Ahli

$\begin{array}{ccc}\text { Aspek } & \begin{array}{c}\text { Persentase Rata- } \\ \text { rata Skor }\end{array} & \text { Kategori } \\ & \end{array}$

\begin{tabular}{|c|c|c|}
\hline Kelayakan isi & 78 & Baik \\
\hline $\begin{array}{l}\text { Kelayakan } \\
\text { penyajian }\end{array}$ & 79,39 & Baik \\
\hline Kelayakan bahasa & 78,33 & Baik \\
\hline $\begin{array}{l}\text { Kelayakan } \\
\text { kegrafikan }\end{array}$ & 82,22 & Sangat Baik \\
\hline \multicolumn{2}{|c|}{ Persentasi Keseluruhan Skor } & 79,49 \\
\hline \multicolumn{2}{|c|}{ Kategori } & Baik \\
\hline
\end{tabular}

Validasi dari aspek kelayakan penyajian oleh ahli dilakukan sebanyak satu kali. Berdasarkan validasi aspek kelayakan isi didapat persentase rata-rata skor $78 \%$ dengan kategori "Baik". Validasi aspek kelayakan penyajian didapat persentase rata-rata skor $79,39 \%$ dengan kategori "Baik". Validasi aspek kelayakan bahasa didapat persentase rata-rata skor $78,33 \%$ dengan kategori "Baik". Validasi aspek kelayakan kegrafikan didapat persentase rata-rata skor 82,22\% dengan kategori "Sangat Baik". Dari hasil tersebut, produk pengembangan bahan ajar menulis teks nonfiksi berdasarkan kelayakan kegrafikan siap digunakan untuk pembelajaran dengan revisi sesuai saran.

Validasi dilakukan oleh tiga ahli. Ahli materi, yaitu Dr. Anwar Efendi, M.Si. Saran yang diperoleh dari ahli materi adalah penrincian aktivitas guru dan siswa pada bagian petunjuk penggunaan buku dan langkah pembelajaran menulis teks yang sama, yaitu dengan menggunakan pendekatan genre yang terdiri atas tiga langkah. Langkah tersebut pemodelan, mengonstruksi teks secara berkelompok, dan mengonstruksi teks secara mandiri.

Ahli kedua adalah ahli bahasa, yaitu Dr. Teguh Setiawan, M.Hum. Saran yang diperoleh dari ahli bahasa adalah teks yang digunakan harus lebih bervariasi (internet, koran, majalah), penggunaan sapaan yang lazim untuk siswa SMP yang awalnya "Anda" kemudian diganti "Kalian", penggunaan kata "kaidah kebahasaan" diganti menjadi "ciri kebahasaan”.
Ahli ketiga adalah ahli kegrafikan, yaitu Dr. Nurhadi, M.Hum. saran yang diperoleh dari ahli kegrafikan adalah penulisan sumber dai internet yang tidak mencantumkan tanggal pengunduhan kemudian dicantumkan, masih ada teks yang belum mencantumkan judul kemudian dicantumkan, tampilan buku terkesan kaku karena banyak garis kemudian ditambah gambar animasi supaya tidak terkesan kaku, dan penambahan praktik menulis pada latian soal poin $B$.

Berdasarkan Tabel 2, dapat disimpulkan bahwa pada aspek kelayakan isi, penyajian, bahasa, dan kegrafikan memperoleh persentase keseluruhan skor 79,49 dengan kategori "Baik". Hal ini menunjukkan bahwa produk yang dikembangkan telah valid untuk diujicobakan karena memenuhi katergori minimal. Kategori minimal dinyatakan valid apabila skor yang didapat minimal antara 4I-60\% menempati kategori "Cukup Baik".

Rekapitulasi data hasil penilaian guru disajikan pada tabel 3 .

Tabel 3. Rekapitulasi Hasil Penilaian Guru

\begin{tabular}{lcc}
\hline \multicolumn{1}{c}{ Aspek } & $\begin{array}{c}\text { Persentase Rata- } \\
\text { rata Skor }\end{array}$ & Kategori \\
\hline Kelayakan isi & 84 & Sangat Baik \\
\hline $\begin{array}{l}\text { Kelayakan } \\
\text { penyajian }\end{array}$ & 84,32 & Sangat Baik \\
\hline Kelayakan bahasa & 81 & Sangat Baik \\
\hline $\begin{array}{l}\text { Kelayakan } \\
\text { kegrafikan }\end{array}$ & 85,98 & Sangat Baik \\
\hline \multicolumn{2}{c}{ Persentasi Keseluruhan Skor } & $\mathbf{8 3 , 8 3}$ \\
\hline \multicolumn{2}{c}{ Kategori } & Sangat Baik \\
\hline
\end{tabular}

Validasi dari aspek kelayakan isi oleh guru dilakukan sebanyak satu kali. Berdasarkan validasi aspek kelayakan isi didapat persentase rata-rata skor 84\% dengan kategori "Sangat Baik". Validasi aspek kelayakan penyajian didapat persentase rata-rata skor $84,32 \%$ dengan kategori "Sangat Baik". Validasi aspek kelayakan bahasa didapat persentase rata-rata skor $81 \%$ dengan kategori "Sangat Baik". Validasi aspek kelayakan kegrafikan didapat persentase ratarata skor 85,98\% dengan kategori "Sangat Baik".

Penilaian produk dilakukan oleh lima guru yang berasal dari sekolah yang berbeda, yaitu SMPN 2 Dlingo dan SMPN 4 Pandak. Guru pertama, yaitu Dra. Sri Winarti (Guru SMPN 2 Dlingo). Saran yang diberikan adalah pemberian warna secara penuh pada penyajian bagan halaman 40. Guru kedua, yaitu Yuli Kiswantini, S.Pd. (Guru SMPN 4 Pandak). Saran yang diperoleh adalah kesalahan penggunaan konjungsi pada kata "koran dan surat kabar" seharusnya "koran atau surat kabar" karena sama dan terdapat penulisan ejaan pada kata "ejsposisi" seharusnya "eksposisi". 
Guru ketiga, yaitu Sunarni, S.Pd. (Guru SMPN 4 Pandak). Saran yang diperoleh adalah penambahan penjelasan mengenai ciri kebahasaan. Guru keempat, yaitu Aulia Muhtiningsih, S.Pd. (Guru SMPN 4 Pandak). Saran yang diperoleh adalah penambahan gambar atau ilustrasi. Guru kelima, yaitu Singgih Prihatmaji, S.Pd. (Guru SMPN 4 Pandak). Saran yang diperoleh adalah sampul buku yang kurang menarik, setelah direvisi sampul diberi warna biru kuning yang terkesan ceria dan diberi animasi anak SMP dan gambar tangan menulis yang menandakan buku tersebut buku untuk menulis.

Berdasarkan penilaian guru pada Tabel 3, dapat disimpulkan bahwa pada aspek kelayakan isi, penyajian, bahasa, dan kegrafikan memperoleh persentase keseluruhan skor 83,83\% dengan kategori "Sangat Baik". Hal ini menunjukkan bahwa produk yang dikembangkan valid untuk diujicobakan karena memenuhi katergori minimal. Kategori minimal dinyatakan valid apabila skor yang didapat minimal antara 4I-60\% menempati kategori "Cukup Baik". Data hasil respon siswa disajikan pada tabel 4.

Tabel 4. Hasil Respon Siswa

\begin{tabular}{llc} 
No. & \multicolumn{1}{c}{ Indikator Penilaian } & $\begin{array}{c}\text { Persenta } \\
\text { se Rata- } \\
\text { rata } \\
\text { Skor }\end{array}$ \\
\hline I. & Materi disajikan dengan jelas & 86 \\
\hline 2. & $\begin{array}{l}\text { Materi yang disajikan mudah } \\
\text { dipahami }\end{array}$ & 82,7 \\
\hline 3. & $\begin{array}{l}\text { Materi yang disajikan sesuai } \\
\text { dengan konteks kehidupan }\end{array}$ & 76,4 \\
\hline 4. & Penyajian kata pengantar & 80,5 \\
\hline 5. & $\begin{array}{l}\text { Penyajian pemetaan Kompetensi } \\
\text { Dasar }\end{array}$ & 80 \\
\hline 6. & $\begin{array}{l}\text { Penyajian tujuan pembelajaran } \\
\text { dalam tiap bab disampaikan } \\
\text { dengan jelas }\end{array}$ & 82,3 \\
\hline 7. & $\begin{array}{l}\text { Penyajian langkah-langkah } \\
\text { kegiatan yang harus dilakukan } \\
\text { jelas }\end{array}$ & \\
\hline 8. & $\begin{array}{l}\text { Penyajian materi dapat menambah } \\
\text { ilmu pengetahuan }\end{array}$ & 84,5 \\
\hline 9. & $\begin{array}{l}\text { Contoh atau ilustrasi yang } \\
\text { disajikan memudahkan saya untuk } \\
\text { memahami materi yang } \\
\text { disampaikan }\end{array}$ & 82,3 \\
\hline I0. & $\begin{array}{l}\text { Penyajian daftar isi yang } \\
\text { memudahkan saya untuk mencari } \\
\text { bagian-bagian yang saya perlukan }\end{array}$ \\
\hline
\end{tabular}

\begin{tabular}{llc}
\hline I1. & $\begin{array}{l}\text { Daftar pustaka disajikan dengan } \\
\text { jelas }\end{array}$ & $\mathbf{8 3 , 2}$ \\
\hline I2. & $\begin{array}{l}\text { Glosarium atau daftar istilah } \\
\text { disajikan dengan jelas }\end{array}$ & 83,2 \\
\hline I3. & $\begin{array}{l}\text { Penyajian gambar atau ilustrasi } \\
\text { selalu mencantumkan sumbernya }\end{array}$ & 84,5 \\
\hline I4. & $\begin{array}{l}\text { Huruf yang digunakan menarik } \\
\text { dan mudah dibaca }\end{array}$ & 87,3 \\
\hline I5. & $\begin{array}{l}\text { Pesan atau maksud yang } \\
\text { disampaikan mudah dipahami }\end{array}$ & 80 \\
\hline I6. & $\begin{array}{l}\text { Bahasa yang digunakan mudah } \\
\text { dipahami }\end{array}$ & 81,4 \\
\hline I7. & $\begin{array}{l}\text { Desain sampul menarik } \\
\text { 18. }\end{array}$ Desain isi buku menarik & 88,2 \\
\hline 19. & $\begin{array}{l}\text { Kualitas kertas yang digunakan } \\
\text { sudah baik }\end{array}$ & 87,3 \\
\hline 20. & $\begin{array}{l}\text { Gambar atau ilustrasi yang } \\
\text { digunakan dalam tiap-tiap judul } \\
\text { pelajaran sudah sesuai }\end{array}$ & 85,5 \\
\hline Rata-rata Persentase Skor Total & $\mathbf{8 3 , 7 6}$ \\
\hline Kategori & Sangat \\
\hline
\end{tabular}

Berdasarkan hasil respon siswa, rata-rata persentase skor total yang diperoleh $83,76 \%$. Hal ini menunjukkan bahwa produk pengembangan bahan ajar menulis teks nonfiksi berkategori "Sangat Baik". Saran yang diberikan siswa yaitu perbaiki tampilan halaman sampul belakang produk pengembangan, perbaiki kesalahan penulisan ejaan, dan penulisan nama sebaiknya tidak disingkat.

Dari hasil tersebut, produk pengembangan bahan ajar menulis teks nonfiksi berbasis pendekatan genre untuk siswa kelas VIII SMP mendapatkan respon yang baik dari siswa. Hal ini dapat dilihat dari ratarata persentase skor total $83,76 \%$ dengan kategori "Sangat Baik".

\section{Simpulan}

Berdasarkan validasi ahli pada aspek kelayakan isi $78 \%$, aspek kelayakan penyajian $79,39 \%$, aspek kelayakan bahasa $78,33 \%$. Ketiga aspek tersebut berkategori "Baik". Pada aspek kelayakan kegrafikan $82,22 \%$ berkategori "Sangat Baik". Rata-rata persentase skor total berdasarkan validasi ahli 79,49\% berkategori "Baik". Berdasarkan penilaian guru pada aspek kelayakan isi $84 \%$, aspek kelayakan penyajian $84,32 \%$, aspek kelayakan bahasa $81 \%$, dan aspek kelayakan kegrafikan 85,98\%. Keempat aspek tersebut berkategori "Sangat Baik".

Rata-rata persentase skor total berdasarkan penilaian guru 83,83\% berkategori "Sangat Baik". Berdasarkan respon siswa sebesar $83,76 \%$ berkategori 
"Sangat Baik". Secara keseluruhan, bahan ajar menulis teks nonfiksi berbasis pendekatan genre berdasarkan validasi ahli, penilaian guru, dan respon siswa memperoleh persentase rata-rata skor $82,36 \%$ berkategori "Sangat Baik". Dengan demikian, bahan ajar ini siap untuk digunakan di sekolah.

\section{Persantunan}

Penulis mengucapkan terima kasih kepada pihak-pihak yang telah membantu dan terlibat dalam artikel ini, yaitu dosen pembimbing Prof. Burhan Nurgiyantoro, guru bahasa Indonesia di SMPN 2 Dlingo dan SMPN 4 Pandak, dan teman-teman Pascasarjana UNY Angkatan 2016. Sukses selalu untuk kita semua.

\section{Daftar Pustaka}

Cope, B., \& Kalantzis, M. (1993). Introduction: How a genre approach to literacy can transform the writing is taught. London: The Flamer Press.

Daryanto, \& Dwicahyono, A. (20I4). Pengembangan perangkat pembelajaran. Yogyakarta: Penerbit Gava Media.

Donoghue, M.R. (2009). Language art integrating skills for classroom teaching. London: Sage Publications, Inc.

Graham, S., Gillespie, A., \& McKeown, D. (2013). Writing: Importance, development, and instruction. Reading and Writing, 26(I), I-I5. Diambil dari https://scihub.tw/ I0.I007/s I I 445-012-9395-2.html.
Harper, G. (2013). A companion to creative writing: Writing creative nonfiction ( $I^{\text {st }} \mathrm{ed}$.). Chichester: John Wiley and Sons.

Hyland, K. (2003). Second language writing. Cambridge: Cambridge University Press.

Johnson, A. P. (2008). Teaching, reading, and writing. America: USA.

Kemendikbud. (2017). Bahasa Indonesia edisi revisi 20I7. Surakarta: PT. Nyata Grafika Media Surakarta.

Kersten, S. (2017). Becoming nonfiction authors: Engaging in science inquiry. The Reading Teacher, 7I(I), 33-4I. Diambil dari http://doi.org/I0.1002/trtr.I577.

Knapp, P., \& Watskins. (2005). Genre, text, grammar: Technology for teaching and assessing writing. Sydney: UNSW Press.

Nurgiyantoro, B. (2016). Penilaian pembelajaran bahasa berbasis kompetensi: Edisi kedua. Yogyakarta: BPFE Yogyakarta.

Pardiyono. (2007). Pasti bisa: Teaching genre-based writing. Yogyakarta: Andi Offset.

Pranowo. (2017). Teori belajar bahasa. Yogyakarta: Pustaka Pelajar.

Riduwan. (2015). Skala pengukuran variabel-variabel penelitian. Bandung: Alfabeta.

Thamrin, M. (2014). Pengembangan bahan ajar penulisan karya ilmiah berbasis vokasi. Litera, I3(I), 90-I02. Diambil dari https://journal.uny.ac.id/index.php/litera/art icle/view/I905/I559. 